ORIGINAL RESEARCH PAPER

\title{
DETOXIFICATION AND NUTRITIONAL ENRICHMENT OF CASSAVA WASTE PULP USING RHIZOPUS OLIGOSPORUS AND ASPERGILLUS NIGER
}

\author{
ADELODUN LAWRENCE KOLAPO ${ }^{1,2 *}$, RAOOFAT OLAMIDE SALAMI ${ }^{2}$, ISMAIL ONAJOBI ${ }^{2}$, \\ FLORA OLUWAFEMI ${ }^{3}$, ABOSEDE OYEYEMI FAWOLE ${ }^{4}$, OLUFUNMILAYO EBUNOLUWA \\ ADEJUMO $^{5}$ \\ ${ }^{I}$ Department of Biological Sciences, Augustine University, Ilara-Epe, Lagos State. Nigeria. \\ ${ }^{2}$ Department of Microbiology, Olabisi Onabanjo University, Ago Iwoye, Nigeria. \\ ${ }^{3}$ Department of Microbiology, Federal University of Agriculture, PMB 2240, Abeokuta, Nigeria. \\ ${ }^{4}$ Department of Biology, The Polytechnic, Ibadan, Nigeria. \\ ${ }^{5}$ Department of Pharmaceutical and Medicinal Chemistry, Faculty of Pharmacy, Olabisi Onabanjo University, \\ Sagamu, Nigeria. \\ *Corresponding author: adelodun.kolapo@augustineuniversity.edu.ng
}

Received on 5 January 2021

Revised on 23 March 2021

\begin{abstract}
The present study evaluated the detoxification and nutritional enrichment potentials of the fermented cassava waste pulp obtained through different processing methods of sweet (S) and bitter (B) cassava varieties by fermentation with Rhizopus oligosporus and Aspergillus niger. Four batches [two with both bark and cortex of the tuber removed (S- and B-), two with bark only removed $(\mathrm{S}+$ and $\mathrm{B}+)$ ] of cassava waste pulp (CWP) were produced from each of $\mathrm{S}$ and B varieties. CWP from the four treatments were then subjected to Rhizopus oligosporus, Aspergillus niger, and natural fermentation. Cyanide (mg HCN/kg), phytate (mg/100g), tannin (mg/100g), $\mathrm{pH}$, crude protein (N X6.25) (\%), ash (\%), Fe, P, K and Ca (mg/100g) content of the unfermented and fermented CWP were determined using standard procedures. The range of the reduction (\%) in cyanide content for Rhizopus oligosporus fermented CWP (RCWP), Aspergillus niger fermented CWP (ACWP), and naturally fermented CWP (NCWP) were 86.24 - 91.95, $79.68-84.34$ and $72.96-$ 78.58 while those for phytate were $58.82-71.20,29.98-39.26$ and $36.16-40.32$ respectively. Fermentation had no significant $(\mathrm{p}>0.05)$ effect on the tannin content while the $\mathrm{pH}$ range of NCWP, RCWP and ACWP were 7.20 - 7.50, 5.41-6.40, and $3.83-4.21$, respectively. The range of the increase $(\%)$ in the protein content for NCWP, RCWP, and ACWP was 346-375, 671-728 and 508-542 while those of the ash content were $7.16-7.91,6.72-6.84$, and 5.42 -5.63 respectively. Of all the examined minerals, only calcium increased by $5.68-26.89,49.96-70.43$, and $59.71-98.87 \%$ in NCWP, RCWP, and ACWP respectively. Results from the present study are indicating that controlled fermentation offers greater benefit over
\end{abstract}

https://doi.org/10.35219/foodtechnology.2021.1.04 
natural fermentation and that the cassava variety and not the peeling method will determine the extent of detoxification and nutrient enrichment.

Keywords: antinutrients, cassava waste pulp, detoxification, enrichment, fermentation, livestock feed

\section{Introduction}

Cassava (Manihot esculenta Crantz) is known to be playing a significant role in the food system of an estimated half-billion people in tropical and subtropical countries. Presently, cassava supplies about $70 \%$ of the daily calorie of over 100 million people in Nigeria. Besides, it serves as a significant source of livestock feed in many parts of the globe. However, in recent times, the industrial potential of cassava for the production of starches for textiles, pharmaceuticals, food, alcohol, acetone, and dextrin industries is largely being exploited (Gunorubon, 2012).

Cassava processing generates large amounts of wastes that contribute significantly to environmental pollution (FAO, 2001; Olukanni and Olatunji, 2018). A study on a starch-producing factory in Nigeria documented by Aro et al. (2010) indicated that daily processing of 120 tonnes of tubers into starch resulted in five waste product streams: $17 \mathrm{t}$ of cassava starch residues, $5 \mathrm{t}$ of cassava peels, $15.4 \mathrm{t}$ of cassava effluent, $8 \mathrm{t}$ of cassava stumps, and $1.51 \mathrm{t}$ of cassava whey. Meanwhile, it has been estimated that the supply-demand gap for cassava starch and high-quality cassava flour in Nigeria are 290,000 and 485,000 metric tons (MT) per annum respectively (PWC, 2020). This corresponds to the respective estimated generation of 870,000 MT and 485,000 MT of cassava pulp as waste annually. It is no doubt that this represents a great environmental threat to communities within the vicinities of the production sites. Therefore, the deployment of appropriate technologies towards the incorporation of these by-products from the primary production of cassava starch or flour into livestock feeding programs is imperative (Aro et al., 2010).

Meanwhile, there are reports on utilization of cassava and its wastes for feeding poultry (Salami and Odunsi, 2003; Omede et al., 2017), pigs (Unigwe et al., 2014), aquaculture (Solomon et al., 1999; Lukuyu et al., 2014; Okoli, 2020), and ruminants (Smith, 1988; Lukuyu et al., 2014; Oloruntola et al., 2019). However, the high cyanogenic glycosides and phytate contents as well as the low protein content of these cassava wastes constitute a restraint to their full exploitation as livestock feed. Different processes found to be effective in reducing cyanogenic glycosides include sun-drying, ensiling, and soaking plus drying (Salami and Odunsi, 2003). However, the processing of agro-allied waste for livestock feed applications should equally target improved nutrient composition in addition to the reduction of innate natural toxins and anti-nutrients. In this regard, reports have shown that fermentation of cassava peels with Saccharomyces cerevisiae and Lactobacillus spp. (Oboh, 2006) and Trichoderma viride (Ezekiel et al., 2010) resulted in a product with higher protein content, lower cyanogenic glycosides, and phytate content. Similarly, Iyayi and Losel (2001) obtained a crude protein of $7.91 \%$ and $9.04 \%$ from the fermentation of cassava pulp using Aspergillus niger and Saccharomyces cerevisiae respectively. 
Major cassava by-products derivable from cassava tubers and leaves which have found application in feeding livestock include cassava leaf, cassava leaf meal, cassava leaf protein concentrate, cassava peels, cassava stumps, cassava sievate, and cassava pomace/pulp/bagasse/starch residue (Lukuyu et al., 2014). Incidentally, studies have shown that cyanogenic glycosides are more concentrated in cassava leaves, root cortex and root parenchyma (Cardoso et. al., 2005; Burns et al., 2012; Ndam et al., 2019). It then becomes imperative for the by-products of these cassava organs to be properly detoxified of cyanogens before they are used as livestock feeds. The nutrient quality of the cassava root varies depending on several factors, such as geographic location, variety, age of the plant, and environmental conditions (Chisenga et al., 2019; Hasmadi et al., 2020). The 'bitter' cassava varieties have a high cyanide content, but they have high starch contents and are thus used in starch processing. On the other hand, the 'sweet' or edible varieties have a low cyanide content, hence, they are mainly used for food and food products (Hasmadi et al., 2020). Similarly, Manano et al. (2018) reported a significant varietal influence on the levels of starch, calcium, magnesium, cyanonenic glucosides and phytates present in cassava roots.

The increasing demand for cassava starch in Nigeria is attracting many medium and large scale industries into the cassava processing sector. To produce cassava starch, the tubers are washed, peeled, washed again, and then grated mechanically to produce cassava pulp. Thereafter, the pulp is then mixed with water and strain/filter with excess water. The residue left after filtration is cassava pomace/pulp/bagasse. The filtrate is either centrifuged or allowed to sediment to produce cassava starch sediment (FAO, 2001). During cassava starch processing, peeling could be done by removal of both the bark and cortex or the bark of the tuber only. Some manufacturers adopt the latter practice on the premise that starch yield is increased.

An investigation that focused on detoxification and nutritional enrichment of cassava waste pulp as affected by processing methods and cassava varieties (sweet and bitter) has not been reported. The objective of the present study is to evaluate the detoxification and nutritional enrichment potentials of the cassava waste pulp obtained from sweet and bitter varieties through different processing methods and fermented by Rhizopus oligosporus and Aspergillus niger.

\section{Materials and methods \\ Materials}

Two varieties of freshly harvested cassava tubers: bitter (B) and sweet (S), were obtained from the Root and Tuber Expansion Programme of International Institute of Tropical Agriculture, located in Ogere, Ogun State Nigeria. The cassava tubers were harvested after 12 months of planting.

The strains, Rhizopus oligosporus and Aspergillus niger, were obtained from the culture collection center of Biological Sciences Department, Augustine University, Ilara-Epe, Lagos State, Nigeria. The strains were isolated from fermenting cassava products. They lack gelatinase and haemolytic activities and exhibited high 
linamarase and amylase activities, as well as tolerant to $2 \%$ bile salt. Stock cultures of these microorganisms stored at $-40^{\circ} \mathrm{C}$ in malt extract broth (Difco, Michigan, USA) containing $20 \%(\mathrm{v} / \mathrm{v})$ glycerol were reactivated by inoculating in malt extract broth (Difco, Michigan, USA) at $28^{\circ} \mathrm{C}$ for $72 \mathrm{~h}$.

\section{Preparation of cassava waste pulp}

The tubers of each of the two varieties (B and S) were peeled using two methods. The first method of peeling was done by removing both the bark (outermost thin brown layer) and the cortex of cassava tuber (B- and S-) while the other method involved the removal of the bark only (B+ and $\mathrm{S}+)$. After peeling, four batches of cassava tuber were obtained. Then, one kilogram of cassava tubers of each of the four batches was washed with tap water at room temperature $\left(29 \pm 1{ }^{\circ} \mathrm{C}\right)$ and grated separately using a mechanical grater to obtain cassava pulp. The pulp was mixed with $0.5 \mathrm{~L}$ of clean tap water and stirred vigorously. The resulting suspension was screened using double layer cheesecloth to extract the cassava starch. The residual mass was rinsed with excess water for about three times to extract as much starch as possible. The residue left thereafter was cassava waste pulp (CWP).

\section{Fermentation of cassava waste pulp}

One hundred grams of each of the four batches of CWP was packed into a salt bag, tied up and subjected to the natural fermentation process for 7 days at $29 \pm 1{ }^{\circ} \mathrm{C}$. Thereafter, the microbiota profile of the fermented samples was determined using standard procedures. One-tenth dilution of the sample was prepared by homogenizing $10 \mathrm{~g}$ of the sample in $90 \mathrm{~mL}$ of sterile buffered peptone water. The homogenate was ten-fold serially diluted using same diluent. Appropriate dilution was pour-plated on Nutrient Agar (NA), MRS Agar (MRSA), and Yeast and Mould Agar (YMA) supplemented with $100 \mathrm{mg} / \mathrm{L}$ chloramphenicol (Oxoid, Basingstoke Hampshire, UK). NA and MRSA plates were incubated at $37^{\circ} \mathrm{C}$ while YMA plates were incubated at $29^{\circ} \mathrm{C}$. Distinct colonies were streaked on the medium of isolation twice to obtain pure cultures. Pure cultures were maintained on agar slants at $4{ }^{\circ} \mathrm{C}$ for further characterization studies. Characterization of bacterial isolates was done using morphological, cultural and biochemical characteristics as described by Barrow and Feltham (2003) while fungal isolates were characterized using morphological, cultural, and physiological characteristics as described by Ebabhi $e t$ al. (2013).

Rhizopus oligosporus and Aspergillus niger were subculture on malt extract agar (Difco, Michigan, USA) and grown for $72 \mathrm{~h}$ at $28^{\circ} \mathrm{C}$. A hundred milliliters $(100 \mathrm{~mL}$ ) of sterile distilled water and 10 drops of Tween 20 were put in a beaker and stirred together using a magnetic stirrer SB 162 (Stuart, Staffordshire, UK). Ten milliliters of the resulting solution were put on a fungal plate and the spores were scraped using a sterile spatula. The spore solution was placed in a beaker and stirred for $10 \mathrm{~min}$. The mixture was filtered using sterile cheesecloth and the spores were counted by using a Neubauer counting chamber.

One hundred grams of cassava waste pulp was put into a conical flask and sterilized at $121{ }^{\circ} \mathrm{C}$ for $15 \mathrm{~min}$ in an autoclave LS-50HJ (Wincom, Hunan, China). After 
cooling to room temperature, $1 \mathrm{~mL}$ of the fungal spore suspension with a concentration of $4.0 \times 10^{6}$ spores $/ \mathrm{mL}$ was inoculated, mixed and fermented for 7 days at $28^{\circ} \mathrm{C}$. After fermentation, all samples were dried in an oven at $55^{\circ} \mathrm{C}$ for 24 $\mathrm{h}$ and were immediately analyzed.

\section{Sample analyses}

The cyanide content of the samples was determined by modified silver nitrate titration method described by Moriasi et al. (2017). Phytate content of the fermented CWP was determined using anion exchange method as described by Ma et al. (2005). Tannins contents of the samples were determined according to the method developed by Burns (1971). The $\mathrm{pH}$ of the samples was determined following the method described by Ogiehor and Ikenebomeh (2005). The protein ( $\mathrm{N}$ x 6.25) and ash content of fermented CWP were determined by AOAC (1990) methods. The mineral $(\mathrm{Fe}, \mathrm{P}, \mathrm{K}$ and $\mathrm{Ca}$ ) analysis of the fermented CWP was carried out using Atomic Absorption Spectrophotometer (Analytikjena AG, Germany) according to the method of Hernandez et al. (2004).

\section{Statistical Analysis}

Data obtained were expressed as means \pm standard deviation. Analysis of variance was carried out on the data obtained to determine the significance of differences. A two-tailed $\mathrm{P}$ value of less than 0.05 was considered to be statistically significant. Values that were significantly different were separated using the Duncan Multiple Range test using SPSS for Windows Version 17.0 statistical package.

\section{Results and discussion}

A total of six bacterial species were isolated from naturally fermented cassava waste pulp (NCWP) and were identified as Bacillus subtilis, B. coagulans, B. cereus, Lactobacillus plantarum, L. brevis, and Pseudomonas spp. The five species of fungi isolated and identified from NCWP were Geotrichum candidum, Saccharomyces pombe, Candida tropicalis, Rhodotorula spp, and Rhizopus spp. The microflora associated with the detoxification of cyanogenic glycosides during spontaneous/natural fermentation of cassava products includes yeast, molds, lactic acid bacteria, and some Bacillus species (Lei et al., 1999). The taxonomic characterization based on morphological, physiological and biochemical data indicated the presence of Rhodotorula glutinis (Fresenius) F. C. Harrison var. glutinis - a linamarin degrading yeast in cassava wastewater treatment lagoons (Vasconcellos et al., 2009). The previous characterization of yeasts ecology of fermented cassava products have documented the presence of different species of the following genera: Saccharomyces, Candida, Hansenula, Penicillium, Geotrichum, Rhodotorula, Pichia and Zygosaccharomyces (Amoa-Awua et al., 1997; Oyewole, 2001; Coulin et al., 2006; Schwan et al., 2007). In another development, Galactomyces spp. was reported to be one of the yeasts involved in the fermentation of sour cassava starch (Lacerda et al., 2005).

The antinutrient contents of the unfermented and fermented CWP processed by different methods are shown in Table 1 . The cyanide content $(\mathrm{mg} \mathrm{HCN} / \mathrm{kg})$ of 
unfermented CWP obtained from B cassava variety (56.75 - 58.12) was significantly higher $(p<0.05)$ than those obtained from $S$ variety $(40.16-42.86)$. However, the method employed for the peeling process did not have a significant effect $(p>0.05)$ on the cyanide content of CWP obtained from the two cassava variety. The cyanide content in the parenchyma of cassava tuber, from which CWP was obtained, is known to range from 10 to $500 \mathrm{mg} \mathrm{HCN} / \mathrm{kg}$ (Siritunga and Sayre, 2003) while Oboh (2006) reported a cyanide level of $44.6 \mathrm{mg} \mathrm{HCN} / \mathrm{kg}$ in unfermented cassava peel. The cyanide content of the unfermented CWP produced from both bitter and sweet cassava varieties in the present study is within the reported range. The fact that there was no significant difference in the cyanide content of CWP obtained by the two peeling methods is possibly indicating that an insignificant amount of cyanide resides in the bark of cassava tuber. This can be linked with the submission of Heuberger (2005) which demonstrated that the cyanide radial-gradient exists in cassava root. This author reported cyanide content of 37, 135 and $282 \mathrm{mg} \mathrm{HCN} / \mathrm{kg}$ fresh weight of cassava root pith, parenchyma and cortex respectively. Similarly, Moriasi et al. (2017) reported a gradual decrease in cyanide concentration from the cortex through to the pith.

Fermentation reduced the cyanide content of the fermented CWP. In this regard, the percentage reduction range in cyanide content for Rhizopus oligosporus fermented cassava waste pulp (RCWP), Aspergillus niger fermented cassava waste pulp (ACWP), and naturally fermented cassava waste pulp (NCWP) were 86.24 - 91.95, $79.68-84.34$, and $72.96-78.58$ respectively. However, there was a significant $(\mathrm{p}<0.05)$ varietal influence on the cyanide content of fermented CWP while peeling methods had no significant effect on its cyanide content. Many different processing methods such as boiling, baking, steaming, frying, soaking, grating, drying, and fermentation are used for the reduction of cyanide content of cassava roots (Montagnac et al., 2009). Nambisan and Sundaresan (1985) demonstrated that boiling 2 -g and 50 -g of cassava root for 30 min resulted in a $75 \%$ and $25 \%$ reduction in cyanide content, respectively. Similarly, cyanogen retention was reduced from $70 \%$ to $24 \%$ by increasing the volume of water from 1 - to 5 -fold. In a related development, Kasaye et al. (2018) reported a $100 \%$ cyanide reduction in cassava flour produced by a combination of soaking and fermentation for $24 \mathrm{~h}$.

The cyanide reduction observed in the present study compares favorably with previous results. The present results indicate that controlled fermentation brought about the highest cyanide reduction in comparison with natural fermentation. Also, each starter culture differed in their abilities to reduce the cyanide content. In a related development, Ahaotu et al. (2011) had reported different linamarase activities for different starter microorganisms used for protein improvement in gari. Similarly, Oboh and Oladunmoye (2007) reported differences in the abilities of Rhizopus oryzae and Saccharomyces cerevisae to reduce the cyanide content of micro-fungi fermented cassava flour. The significant cassava varietal influence on the cyanide content of fermented CWP observed in the present study is similar to the report of Oboh and Oladunmoye (2007) on low and medium-cyanide cassava varieties that were fermented for the production of cassava flour. The relatively 
lower cyanide reduction observed in the fermentation of CWP obtained from cassava bitter variety might be attributed to the high cyanide content of bitter variety which could have slightly inhibited the growth and metabolism of the fermenting microorganisms.

Table 1. Antinutrient composition of fermented cassava waste pulp obtained through different processing methods.

\begin{tabular}{|c|c|c|c|}
\hline \multirow[b]{3}{*}{ Antinutrient } & \multirow[b]{3}{*}{$\begin{array}{l}\text { Fermentation } \\
\text { method }\end{array}$} & \multicolumn{2}{|c|}{ Cassava Variety } \\
\hline & & \multicolumn{2}{|c|}{ TME $419 \quad$ (Sweet variety) } \\
\hline & & $\begin{array}{l}\text { Bark and cortex } \\
\text { of tuber removed }\end{array}$ & $\begin{array}{l}\text { Only bark of tuber } \\
\text { removed }\end{array}$ \\
\hline \multirow{4}{*}{$\begin{array}{l}\text { Cyanide } \\
(\mathrm{mg} \mathrm{HCN} / \mathrm{kg})\end{array}$} & UCWP & $40.16 \pm 1.23^{\mathrm{a}}$ & $42.86 \pm 2.13^{\mathrm{a}}$ \\
\hline & NCWP & $10.86 \pm 0.63^{\mathrm{b}} \quad(72.96)$ & $10.67 \pm 0.2^{\mathrm{b}} \quad(75.10)$ \\
\hline & RCWP & $3.62 \pm 0.13^{\mathrm{c}} \quad(90.99)$ & $3.45 \pm 0.15^{\mathrm{c}} \quad(91.95)$ \\
\hline & ACWP & $8.16 \pm 0.21^{\mathrm{b}} \quad(79.68)$ & $8.11 \pm 0.33^{\mathrm{b}}$ \\
\hline \multirow{4}{*}{$\begin{array}{l}\text { Phytate } \\
(\mathrm{mg} / 100 \mathrm{~g})\end{array}$} & UCWP & $1169.75 \pm 3.24^{\mathrm{a}}$ & $1158.42 \pm 5.27^{\mathrm{a}}$ \\
\hline & NCWP & $742.80 \pm 2.03^{b} \quad(36.50)$ & $705.13 \pm 2.13^{b} \quad(39.13)$ \\
\hline & RCWP & $336.85 \pm 5.28^{\mathrm{d}} \quad(71.20)$ & $334.25 \pm 3.03^{\mathrm{c}}(71.15)$ \\
\hline & ACWP & $710.46 \pm 1.14^{c} \quad(39.26)$ & $709.20 \pm 1.88^{\mathrm{b}} \quad(38.77)$ \\
\hline \multirow{5}{*}{$\begin{array}{l}\text { Tannin } \\
(\mathrm{mg} / 100 \mathrm{~g})\end{array}$} & UCWP & $389.10 \pm 1.63^{\mathrm{a}}$ & $390.81 \pm 0.99^{\mathrm{a}}$ \\
\hline & NCWP & $292.40 \pm 4.21^{\mathrm{b}} \quad(24.85)$ & $288.79 \pm 1.23^{\mathrm{b}} \quad(26.10)$ \\
\hline & RCWP & $388.78 \pm 1.54^{\mathrm{a}} \quad(0.08)$ & $390.10 \pm 1.04^{\mathrm{a}} \quad(0.18)$ \\
\hline & ACWP & $388.52 \pm 2.43^{\mathrm{a}} \quad(0.15)$ & $388.70 \pm 0.86^{\mathrm{a}} \quad(0.54)$ \\
\hline & & \multicolumn{2}{|c|}{$\begin{array}{ll}\text { TMS 92/0067 } & \text { (Bitter variety) } \\
\end{array}$} \\
\hline \multirow{4}{*}{$\begin{array}{l}\text { Cyanide } \\
(\mathrm{mg} \mathrm{HCN} / \mathrm{kg})\end{array}$} & UCWP & $56.75 \pm 1.13^{\mathrm{a}}$ & $58.12 \pm 2.03^{\mathrm{a}}$ \\
\hline & NCWP & $12.69 \pm 0.27^{\mathrm{b}}(77.64)$ & $12.45 \pm 0.73^{\mathrm{b}}(78.58)$ \\
\hline & RCWP & $7.81 \pm 0.21^{\mathrm{c}} \quad(86.24)$ & $7.92 \pm 0.23^{\mathrm{c}} \quad(86.37)$ \\
\hline & ACWP & $8.92 \pm 0.13^{\mathrm{c}} \quad(84.28)$ & $9.10 \pm 0.12^{\mathrm{c}} \quad(84.34)$ \\
\hline \multirow{4}{*}{$\begin{array}{l}\text { Phytate } \\
(\mathrm{mg} / 100 \mathrm{~g})\end{array}$} & UCWP & $1024.99 \pm 6.28^{\mathrm{a}}$ & $1043.72 \pm 2.43^{\mathrm{a}}$ \\
\hline & NCWP & $654.33 \pm 3.43^{\mathrm{c}} \quad(36.16)$ & $622.91 \pm 3.23^{\mathrm{c}} \quad(40.32)$ \\
\hline & RCWP & $422.10 \pm 6.03^{\mathrm{d}} \quad(58.82)$ & $421.66 \pm 4.03^{\mathrm{d}} \quad(59.60)$ \\
\hline & ACWP & $717.70 \pm 2.13^{\mathrm{b}}(29.98)$ & $715.56 \pm 5.63^{\mathrm{b}} \quad(31.44)$ \\
\hline \multirow{4}{*}{$\begin{array}{l}\text { Tannin } \\
(\mathrm{mg} / 100 \mathrm{~g})\end{array}$} & UCWP & $298.22 \pm 1.03^{\mathrm{a}}$ & $299.07 \pm 1.03^{\mathrm{a}}$ \\
\hline & NCWP & $297.00 \pm 0.83^{\mathrm{a}}$ & $284.22 \pm 1.23^{\mathrm{b}} \quad(4.97)$ \\
\hline & RCWP & $298.12 \pm 2.03^{\mathrm{a}}$ & $299.04 \pm 0.93^{\mathrm{a}} \quad(0.01)$ \\
\hline & ACWP & $296.11 \pm 1.53^{\mathrm{a}}$ & $297.79 \pm 1.16^{\mathrm{a}} \quad(0.43)$ \\
\hline
\end{tabular}

Values are means \pm standard deviation $(n=3)$. Values in bracket are percentage reduction of the respective antinutrient content. For each antinutrient, values in the same column with different superscripts are significantly different $(\mathrm{p}<0.05)$. UCWP $=$ unfermented Cassava waste pulp. NCWP = naturally fermented Cassava waste pulp. $\mathrm{RCWP}=$ Rhizopus oligosporus fermented Cassava waste pulp. $\mathrm{ACWP}=$ Aspergillus niger fermented Cassava waste pulp.

The range of phytate content $(\mathrm{mg} / 100 \mathrm{~g})$ for unfermented cassava waste pulp obtained from S and B varieties were 1158.42 - 1169.75 and 1024.99 - 1043.72 respectively. Oboh (2006) had reported a phytate content of $1043.6 \mathrm{mg} / 100 \mathrm{~g}$ in unfermented cassava peel. Both natural and starter culture fermentation significantly 
reduced the phytate contents to $334.25-742.80$ and $421.66-717.70$ respectively. Consequently, $36.16-40.32,58.82-71.20$ and $29.98-39.26$ percentage reduction were observed in NCWP, RCWP and ACWP respectively. Cassava variety used had a significant $(\mathrm{p}<0.05)$ influence on the phytate content of fermented CWP while the peeling method employed had no significant effect $(p>0.05)$ on the phytate content.

The phytate content of fermented CWP obtained in the present study is similar to those reported by Kasaye et al. (2018) (416.8 - 809.48), Oboh and Oladunmoye (2007) (112.8 - 282.1), Oboh (2006) (705.1 - 789.7) for fermented cassava flour and peels. Phytate (inositol hexakisphosphate) is a regulator of intracellular signaling and a form of phosphate storage in plant seeds, but it can bind proteins and minerals in the gastrointestinal tract preventing absorption and utilization by the body (Montagnac et al., 2009). Phytates are known to interfere with the absorption of divalent metals, such as iron and zinc, which are essential nutrients. Marfo et al. (1990) and Kasaye et al. (2018) reported that fermentation of cassava could bring about 85.6 and $48.5 \%$ reduction in phytate content respectively. The \% phytate reduction observed in the present study is similar to these earlier reports. The results of the present study are also indicating that starter culture fermentation, especially that mediated by Rhizopus oligosporus has a comparative advantage over natural fermentation. This is possibly indicating that the usual practice of feeding livestock with naturally fermented cassava waste by smallholder farmers might constitute a nutritional and health risk to such livestock as the elevated level of phytate in such feed might reduce the bioavailability of some essential nutrients such as $\mathrm{Fe}$ and Zinc.

The tannin content $(\mathrm{mg} / 100 \mathrm{~g})$ of unfermented cassava waste pulp obtained from $\mathrm{S}$ variety $(389.10-390.81)$ was significantly higher $(\mathrm{p}<0.05)$ than those $(298.22-$ $299.07)$ obtained from $B$ variety as the peeling method did not significantly ( $p>0.05)$ influence the tannin content. The tanning content of the unfermented CWP in the present study compares favorably with that reported by Oboh and Oladunmoye (2007). Starter culture fermentation which employed both Rhizopus oligosporus and Aspergillus niger had no significant $(\mathrm{p}>0.05)$ reduction effect on the tannin content of the fermented CWP. However, natural fermentation brought about a percentage reduction of $0.41-26.10$ in the tannin content of fermented CWP. Oboh and Oladunmoye (2007) reported a tannin content of $0.4 \%(400 \mathrm{mg} / 100 \mathrm{~g})$ in both low and medium cyanide unfermented cassava flour. According to these authors, the tannin level significantly dropped to $0.1-0.2 \%(100-200 \mathrm{mg} / 100 \mathrm{~g})$ after fermentation. In a related development, the range of tannin content of the fermented CWP in the present study was $0.284-0.390 \%(284-390 \mathrm{mg} / 100 \mathrm{~g})$. Though both controlled and natural fermentation did not possess the capacity to significantly detoxify tannin in CWP; yet the fermented CWP will not constitute a nutritional and health risk to livestock at $<1 \%$ concentration observed in the present study. This become more plausible as Yacout (2016) had stated that tannins have many known advantages on animal health at lower concentration but only reduce nutrient utilization at concentration higher than $7 \%$.

Figure 1 shows the $\mathrm{pH}$ of the unfermented and fermented CWP processed by different methods. The $\mathrm{pH}$ of unfermented cassava waste pulp ranged between 5.61 
and 6.60. This is comparable to 6.48 and 6.69 reported by Kasaye et al. (2018) for unfermented cassava flour and yam flour respectively. The $\mathrm{pH}$ of unfermented CWP obtained by the removal of both cortex and bark $(6.21-6.60)$ was significantly higher $(p<0.05)$ than those obtained from the removal of the bark only $(5.61-5.80)$. This is suggesting that the cortex likely contained acidic compounds or compounds that turned acidic sequel to processing steps such as grating. Cyanogenic glycoside and its hydrolytic enzymes- linamarase are differentially compartmentalized in plant tissues. The former is vacuole bound while the latter is a cell wall and/or laticiferlocalized $\beta$-glucosidase (Gruhnert et al., 1994; Enneking and Wink, 2000). Tissue disruption steps such as grating, pounding, and maceration causes linamarin and linamarase to be decompartmentalized and come in contact, thus resulting in the hydrolysis of the former to glucose and cyanohydrin, which subsequently degrades to acetone and hydrogen cyanide (Duodu and Apea-Bah, 2017). Heuberger (2005) had previously reported that the cassava root cortex contains the highest amount of cyanogenic glycosides. The hydrolysis of these cyanogens in the cortex to cyanohydrin and its subsequent degradation to hydrogen cyanide, sequel to grating, might be responsible for the significantly lower $\mathrm{pH}$ observed in the unfermented CWP obtained from the removal of the bark only.

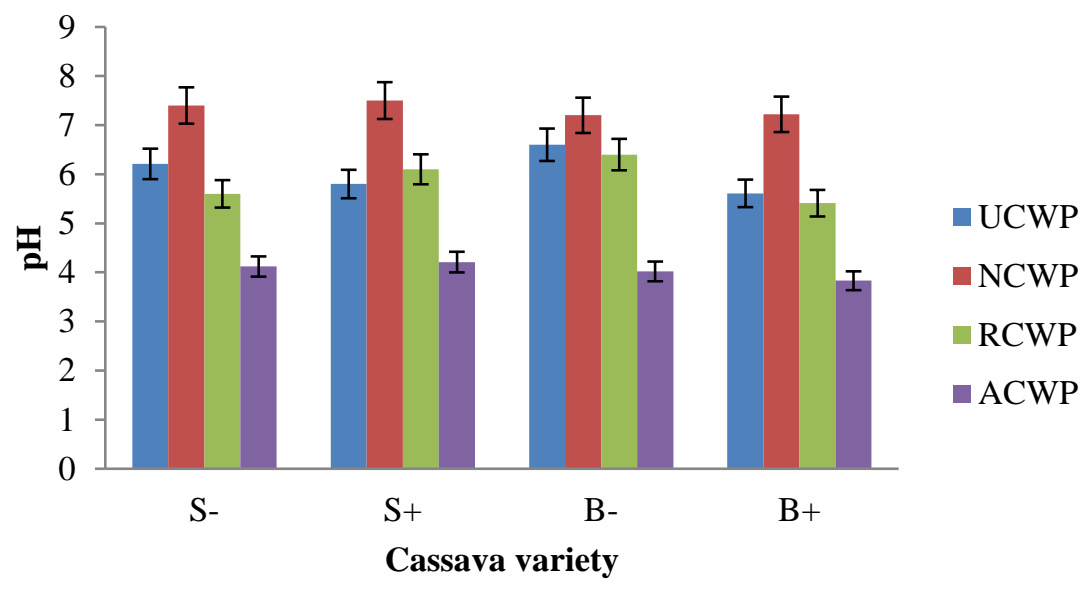

Figure 1. $\mathrm{pH}$ values of fermented cassava waste pulp obtained through different processing methods. UCWP = unfermented Cassava waste pulp, NCWP= naturally fermented Cassava waste pulp, RCWP $=$ Rhizopus oligosporus fermented Cassava waste pulp, ACWP= Aspergillus niger fermented Cassava waste pulp. S- $=$ Sweet variety with both bark and cortex of the tuber removed. S+= Sweet variety with bark of the tuber only removed. B- = Bitter variety with both bark and cortex of the tuber removed. B+= Bitter variety with bark of the tuber only removed.

The $\mathrm{pH}$ range of NCWP, RCWP, and ACWP was 7.20 - 7.50, 5.41-6.40, and 3.83 -4.21 respectively. However, Kasaye et al. (2018) reported the $\mathrm{pH}$ values of 3.37 and 3.54 for fermented cassava flour and yam flour respectively. The $\mathrm{pH}$ of the naturally fermented CWP was in the slightly alkaline range while those fermented 
using starter cultures $R$. oligosporus and A. niger are in the acidic range. Most bacteria, except for acid bacteria, grow best between $\mathrm{pH} 5.5$ and 7.0 and do not thrive in acidic environment (Kwon et al., 2014). However, yeasts and molds predominate in low $\mathrm{pH}$ foods where bacteria cannot compete (Aggie Horticulture, 2021). Microflora associated with detoxification of cyanogenic glycosides during spontaneous/natural fermentation of cassava products includes yeast, molds, lactic acid bacteria, and some Bacillus species (Lei et al., 1999).

In the present study, controlled fermentation using the molds - $R$. oligosporus and $A$. niger resulted in the products with $\mathrm{pH}$ range of $3.83-6.40$. The slightly alkaline $\mathrm{pH}$ of naturally fermented CWP is possibly a reflection of the involvement of bacteria in addition to fungi such as yeasts and molds.

Table 2 shows the protein and ash contents of the unfermented and fermented CWP processed by different methods.

Table 2. Protein and ash content of fermented cassava waste pulp obtained through different processing methods.

\begin{tabular}{|c|c|c|c|}
\hline \multirow[b]{3}{*}{ Parameter } & \multirow[b]{3}{*}{$\begin{array}{l}\text { Fermentation } \\
\text { method }\end{array}$} & \multicolumn{2}{|c|}{ Cassava variety } \\
\hline & & \multicolumn{2}{|c|}{ TME $419 \quad$ (Sweet variety) } \\
\hline & & $\begin{array}{l}\text { Bark and cortex } \\
\text { of tuber removed }\end{array}$ & $\begin{array}{l}\text { Only bark of tuber } \\
\text { removed }\end{array}$ \\
\hline Protein & UCWP & $3.48 \pm 0.97^{\mathrm{d}}$ & $3.52 \pm 0.47^{\mathrm{d}}$ \\
\hline \multirow[t]{3}{*}{$(\%)$} & NCWP & $16.51 \pm 1.03^{c}(374)$ & $16.72 \pm 0.83^{c}(375)$ \\
\hline & RCWP & $28.82 \pm 0.03^{\circ}(728)$ & $28.45 \pm 0.44^{\mathrm{a}}(708)$ \\
\hline & ACWP & $22.34 \pm 0.34^{\mathrm{b}}(542)$ & $22.11 \pm 0.24^{\mathrm{b}}(528)$ \\
\hline Ash & UCWP & $0.82 \pm 0.13^{\mathrm{d}}$ & $0.88 \pm 0.09^{c}$ \\
\hline \multirow[t]{4}{*}{$(\%)$} & NCWP & $7.91 \pm 0.04^{\mathrm{a}}(865)$ & $7.16 \pm 0.09^{\mathrm{a}}(714)$ \\
\hline & RCWP & $6.84 \pm 0.03^{b}(734)$ & $6.81 \pm 0.03^{\mathrm{a}}(674)$ \\
\hline & ACWP & $5.42 \pm 0.05^{\mathrm{c}}(561)$ & $5.48 \pm 0.05^{b} \quad(523)$ \\
\hline & & \multicolumn{2}{|r|}{ (Bitter variety) } \\
\hline \multirow{4}{*}{$\begin{array}{l}\text { Protein } \\
(\%)\end{array}$} & UCWP & $3.36 \pm 0.16^{\mathrm{d}}$ & $3.42 \pm 0.23^{\mathrm{d}}$ \\
\hline & NCWP & $15.48 \pm 0.23^{\mathrm{c}}(361)$ & $15.26 \pm 0.10^{\mathrm{c}}(346)$ \\
\hline & RCWP & $26.58 \pm 0.19^{\mathrm{a}}(691)$ & $26.36 \pm 0.32^{\mathrm{a}}(671)$ \\
\hline & ACWP & $20.44 \pm 0.21^{\mathrm{b}}(508)$ & $20.86 \pm 0.10^{\mathrm{b}}(510)$ \\
\hline & UCWP & $0.88 \pm 0.06^{\mathrm{c}}$ & $0.91 \pm 0.11^{\mathrm{c}}$ \\
\hline \multirow[t]{3}{*}{$(\%)$} & NCWP & $7.18 \pm 0.03^{\mathrm{a}}(716)$ & $7.21 \pm 0.04^{\mathrm{a}}(692)$ \\
\hline & RCWP & $6.78 \pm 0.04^{\mathrm{a}}(670)$ & $6.72 \pm 0.08^{\mathrm{a}}(638)$ \\
\hline & ACWP & $5.52 \pm 0.01^{\mathrm{b}}(527)$ & $5.63 \pm 0.14^{\mathrm{b}}(519)$ \\
\hline
\end{tabular}

Values are means \pm standard deviation $(n=3)$; Values in bracket are percentage increase of the respective nutrient content. For each parameter, values in the same column with different superscripts are significantly different $(\mathrm{p}<0.05)$. UCWP $=$ unfermented Cassava waste pulp, NCWP $=$ naturally fermented Cassava waste pulp. $\mathrm{RCWP}=$ Rhizopus oligosporus fermented Cassava waste pulp. $\mathrm{ACWP}=$ Aspergillus niger fermented Cassava waste pulp.

The protein content (\%) of unfermented CWP ranged between 3.36 and 3.52 with cassava variety and peeling methods having no significant effect ( $p>0.05)$ on these 
values. After fermentation, the protein content was greatly enriched. The range of protein content for NCWP, RCWP, and ACWP was $15.26-16.72,26.36-28.82$, and $20.44-22.34$ respectively. In this regard, $R$. oligosporus fermentation brought about a $671-728 \%$ increase in the protein content of the fermented CWP. The least protein enrichment of $346-375 \%$ was mediated by natural fermentation. Both cassava variety and peeling method used for generating CWP had no significant effect ( $p>0.05$ ) on the protein content of the fermented CWP. Earlier studies on solid-state fermentation of cassava pulp and cassava peels using Aspergillus niger and Saccharomyces cerevisiae increased the protein content to $7.91-9.04$ and 14.14 - $16.74 \%$ respectively (Iyayi and Losel, 2001). Using $R$. oryzae and S. cerevisiae, Oboh and Oladunmoye (2007) reported protein content of 8.8-12.6\% in fermented cassava flour as Kolapo and Sanni (2009) documented a protein content of $1.0-1.5$ $\%$ in naturally fermented gari. Natural and starter culture fermentation of cassava peel using S. cerevisiae and Lactobacillus spp. have been reported to increase the protein content to 11.1 and $21.5 \%$ respectively (Oboh,2006).

The ash content (\%) of unfermented CWP ranged between 0.82 and 0.91 with cassava variety and peeling methods having no significant effect ( $p>0.05)$ on these values. Fermentation resulted to increase in the ash content of fermented CWP. Out of the three modes of fermentation, natural fermentation resulted in the highest ash increment while cassava variety and peeling methods had no significant effect ( $p$ > 0.05) on the ash content of fermented CWP. Oboh (2006) reported the ash content of 6.0 and $7.2 \%$ for natural and inoculated fermented cassava peel as Asaolu et al. (2012) reported a value of $4.9 \%$. Similarly, Mutayoba et al. (2012) reported an ash content range of $4.3-6.9 \%$ for stored frozen, dried, and ground cassava peel.

The mineral ( $\mathrm{Fe}, \mathrm{P}, \mathrm{K}$, and $\mathrm{Ca}$ ) composition $(\mathrm{mg} / 100 \mathrm{~g})$ of both the unfermented and fermented CWP is shown in Table 3. The Fe, P, K, and Ca content of the unfermented CWP were $0.271-0.281,25.812-27.011,245.101-255.341$, and $15.131-19.480$ respectively. Fermentation resulted in non-significant $(p>0.05)$ changes in the $\mathrm{Fe}$ content of the fermented CWP. Both P and K contents of the fermented CWP decreased significantly $(\mathrm{p}<0.05)$ following fermentation. However, the Ca contents of the fermented CWP increased significantly $(\mathrm{p}<0.05)$ following fermentation. In this regard, A. niger brought about the highest $\%$ increase (59.71 - 98.87) and natural fermentation the least $(5.68$ - 26.89). It appears that the highest \% increase was observed in the CWP obtained by the removal of the bark only.

Mutayoba et al. (2012) reported Fe content (mg/100 g) of $44-66$ for stored frozen, dried, and ground cassava peel while Heuze (2012) a value of 6 for fresh unfermented pomace (cassava waste pulp). Potassium has been reported to be present at the levels of $0.01,0.05-0.06$, and $1.25-1.52$ in fresh unfermented pomace, unfermented and fermented peels, and stored frozen dried and ground cassava peel respectively (Oboh, 2006; Heuze, 2012; Mutayoba et al., 2012). In another development, Ca content (mg/100g) of 0.03, 0.56, $0.69-1.25$ and 1.33 are present in unfermented and fermented peels, fresh unfermented pomace, stored, frozen dried and ground cassava peel, cassava peel meal respectively (Oboh, 2006; Heuze, 2012; Mutayoba et al., 2012). 
Table 3. Mineral composition $(\mathrm{mg} / 100 \mathrm{~g})$ of fermented cassava waste pulp obtained through different processing methods.

\begin{tabular}{|c|c|c|c|}
\hline \multirow[b]{3}{*}{ Mineral } & \multirow[b]{3}{*}{$\begin{array}{l}\text { Fermentation } \\
\text { method }\end{array}$} & \multicolumn{2}{|c|}{ Cassava Variety } \\
\hline & & \multicolumn{2}{|c|}{ TME 419 (Sweet variety) } \\
\hline & & $\begin{array}{l}\text { Bark and cortex of } \\
\text { tuber removed }\end{array}$ & $\begin{array}{l}\text { Only bark of tuber } \\
\text { removed }\end{array}$ \\
\hline \multirow{4}{*}{ Iron } & UCWP & $0.275 \pm 0.021^{\mathrm{a}}$ & $0.271 \pm 0.031^{\mathrm{a}}$ \\
\hline & NCWP & $0.292 \pm 0.021^{\mathrm{a}}(+6.18)$ & $0.294 \pm 0.011^{\mathrm{a}}(+8.49)$ \\
\hline & RCWP & $0.210 \pm 0.012^{\mathrm{a}}(-23.64)$ & $0.211 \pm 0.009^{\mathrm{a}}(-22.14)$ \\
\hline & ACWP & $0.258 \pm 0.011^{\mathrm{a}}(-6.18)$ & $0.264 \pm 0.014^{\mathrm{a}}(-2.58)$ \\
\hline \multirow[t]{4}{*}{ Phosphorus } & UCWP & $25.812 \pm 0.011^{\mathrm{a}}$ & $26.116 \pm 0.012^{\mathrm{a}}$ \\
\hline & NCWP & $25.216 \pm 0.091^{\mathrm{a}}(-2.31)$ & $25.413 \pm 0.009^{a}(-2.69)$ \\
\hline & RCWP & $20.819 \pm 0.004^{\mathrm{c}}(-19.34)$ & $21.617 \pm 0.012^{\mathrm{b}} \quad(-17.23)$ \\
\hline & ACWP & $22.724 \pm 0.009^{b}(-11.96)$ & $22.921 \pm 0.010^{\mathrm{b}} \quad(-12.23)$ \\
\hline \multirow[t]{4}{*}{ Potassium } & UCWP & $255.341 \pm 0.110^{\mathrm{a}}$ & $255.101 \pm 0.112^{\mathrm{a}}$ \\
\hline & NCWP & $212.301 \pm 0.102^{c}(-16.86)$ & $211.617 \pm 0.101^{b}(-17.05)$ \\
\hline & RCWP & $207.901 \pm 0.091^{\mathrm{c}}(-18.57)$ & $206.331 \pm 0.116^{c}(-19.12)$ \\
\hline & ACWP & $245.112 \pm 0.107^{\mathrm{b}}(-4.01)$ & $200.671 \pm 0.009^{c}(-21.34)$ \\
\hline \multirow[t]{6}{*}{ Calcium } & UCWP & $19.480 \pm 0.041^{\mathrm{c}}$ & $19.311 \pm 0.009^{c}$ \\
\hline & NCWP & $20.586 \pm 0.091^{\mathrm{c}}(+5.68)$ & $20.637 \pm 0.071^{\mathrm{c}}(+6.87)$ \\
\hline & RCWP & $29.212 \pm 0.100^{\mathrm{a}}(+49.96)$ & $29.536 \pm 0.008^{\mathrm{b}}(+52.95)$ \\
\hline & ACWP & $31.111 \pm 0.009^{\mathrm{a}}(+59.71)$ & $32.421 \pm 0.009^{\mathrm{a}}(+67.89)$ \\
\hline & & $\begin{array}{l}\text { TMS 92/0067 } \\
\end{array}$ & (Bitter variety) \\
\hline & UCWP & $0.277 \pm 0.014^{\mathrm{b}}$ & $0.281 \pm 0.061^{\mathrm{b}}$ \\
\hline \multirow[t]{3}{*}{ Iron } & NCWP & $0.317 \pm 0.016^{\mathrm{a}}(+14.44)$ & $0.304 \pm 0.011^{\mathrm{a}}(+8.18)$ \\
\hline & RCWP & $0.316 \pm 0.014^{\mathrm{a}}(+14.08)$ & $0.312 \pm 0.016^{\mathrm{a}}(+11.03)$ \\
\hline & ACWP & $0.276 \pm 0.015^{\mathrm{b}}(-0.36)$ & $0.268 \pm 0.018^{\mathrm{b}}(-4.63)$ \\
\hline \multirow[t]{4}{*}{ Phosphorus } & UCWP & $26.712 \pm 0.010^{\mathrm{a}}$ & $27.011 \pm 0.011^{\mathrm{a}}$ \\
\hline & NCWP & $24.304 \pm 0.004^{\mathrm{b}}(-9.01)$ & $25.934 \pm 0.009^{\mathrm{a}}(-3.99)$ \\
\hline & RCWP & $22.082 \pm 0.001^{\mathrm{c}}(-17.33)$ & $22.871 \pm 0.008^{\mathrm{c}}(-15.33)$ \\
\hline & ACWP & $23.415 \pm 0.003^{\mathrm{b}}(-12.34)$ & $23.634 \pm 0.011^{\mathrm{b}}(-12.50)$ \\
\hline \multirow[t]{4}{*}{ Potassium } & UCWP & $245.101 \pm 0.151^{\mathrm{a}}$ & $247.310 \pm 0.121^{\mathrm{a}}$ \\
\hline & NCWP & $204.314 \pm 0.110^{c}(-16.64)$ & $216.114 \pm 0.138^{b}(-12.61)$ \\
\hline & RCWP & $211.671 \pm 0.162^{\mathrm{b}}(-13.64)$ & $204.967 \pm 0.115^{\mathrm{c}}(-17.12)$ \\
\hline & ACWP & $206.106 \pm 0.101^{\mathrm{c}}(-15.19)$ & $200.345 \pm 0.101^{\mathrm{c}}(-18.99)$ \\
\hline \multirow[t]{4}{*}{ Calcium } & UCWP & $15.511 \pm 0.008^{\mathrm{d}}$ & $15.131 \pm 0.019^{\mathrm{d}}$ \\
\hline & NCWP & $18.411 \pm 0.021^{\mathrm{c}}(+18.70)$ & $19.200 \pm 0.031^{\mathrm{c}}(+26.89)$ \\
\hline & RCWP & $26.436 \pm 0.042^{b}(+70.43)$ & $24.760 \pm 0.023^{\mathrm{b}}(+63.64)$ \\
\hline & ACWP & $30.154 \pm 0.089^{a}(+94.40)$ & $30.091 \pm 0.051^{\mathrm{a}}(+98.87)$ \\
\hline
\end{tabular}

Values are means \pm standard deviation $(n=3)$; Values in bracket are percentage change of the respective mineral content (negative and positive value indicate reduction and increase respectively). For each mineral, values in the same column with different superscripts are significantly different $(\mathrm{p}<0.05)$.

$\mathrm{UCWP}=$ unfermented Cassava waste pulp, $\mathrm{NCWP}=$ naturally fermented Cassava waste pulp, RCWP= Rhizopus oligosporus fermented Cassava waste pulp, ACWP $=$ Aspergillus niger fermented Cassava waste pulp. 
The decrease in both the P and K content of fermented CWP might be consequent upon their uptake for metabolic activities of the microorganisms that mediated the fermentation process. Calcium pumps are a group of ion transporters found in the cell membranes. They play a significant role in the active transport of calcium out of the cell for the maintenance of the $\mathrm{Ca}^{2+}$ electrochemical gradient across the cell membrane. They are known to be playing a crucial role in proper cell signaling by keeping the intracellular calcium concentration roughly 10,000 times lower than the extracellular concentration (Carafoli, 1991). This physiological process might be responsible for the elevation of Ca content of fermented CWP obtained through natural and starter culture fermentation. The Ca enrichment of the fermented CWP observed in the present study is similar to a 2.4-fold increase in calcium content of Moringa leaves (MOL) which were fermented by the mixture of Lactobacillus reuteri, Lactobacillus acidophilus, and Candida utilis (Dai et al., 2020). These authors reported that feeding such fermented MOL to calcium-deficient rats increased calcium bioavailability of MOL, promote the growth and development of calcium-deficient rats, bone calcium deposition, and bone growth; enhance bone strength; reduce bone resorption; and prevent calcium deficiency.

Okafor and Nwabuko (2003) reported that the mean cyanide content of cyanogenic plant materials used in feed formulation in Umuahia, Nigeria, ranged from 85.60 to $888.10 \mathrm{mg} / \mathrm{kg}$. These authors further stated that based on the experience from European Community countries; a level of cyanogen below $50 \mathrm{mg}$ HCN equivalent $/ \mathrm{kg}$ was suggested as the target for cassava-based livestock rations. In another development, Viveros et al. (2000) reported that the range of phytate contents $(\%)$ in cereal, legumes, oilseeds, and cereal by-products used as feed ingredients were $0.17-0.23,0.08-0.33,0.34-0.76$, and $0.68-0.88$ respectively. The anti-diarrhea, anti-bacterial, anti-oxidant, free-radical scavenging, and antiproliferative activity in liver cells are the known advantages of tannins on animal health, however at concentration higher than $7 \%$, they usually reduce nutrient utilization (Yacout, 2016). In consideration of detoxification, protein, and calcium enrichment observed in the fermented CWP (especially RCWP) in the present study, it is not in doubt that this fermented cassava residue has the potential replacement value for conventional materials that are commonly used as ingredients in livestock rations.

Various studies have documented the replacement value of processed cassava root/ peels as an energy ingredient when paired with appropriate nitrogen sources, substituting for maize at up to $40 \%$ of total diets in cattle, 20 to $50 \%$ in small herbivores (goats, sheep, rabbits), and up to $100 \%$ in swine diets, 10 to $40 \%$ in various poultry diets, and $15-30$ to $>60 \%$ in aquaculture diets (depending on species/age) (Lukuyu et al., 2014). Given the level of detoxification obtained for cyanide and phytate contents, and enrichment obtained for protein, ash, and $\mathrm{Ca}$ contents in the present study, fermented CWP obtained using $R$. oligosporus and A. niger could be further subjected to animal feeding investigation to determine whether it could demonstrate replacement value for maize in livestock and aquaculture feeding programs. 


\section{Conclusions}

Results from the present study are indicating that the fermentation of CWP by using $R$. oligosporus and A. niger offers greater benefit over natural fermentation, especially with respect to cyanide and phytate detoxication, and protein and calcium enrichment. Also, data from the study suggest that the cassava variety and not peeling methods often used during cassava starch processing will determine the extent of detoxification and nutrient enrichment observed in the fermented CWP.

\section{References}

Aggie Horticulture. 2021. Food technology and processing. Texas A \& M University System. https://aggie-horticulture.tamu.edu/food-technology/food-processingentrepreneurs/microbiology-of-food/ (Accessed on 09/02/2021)

Ahaotu, I., Ogueke, C.C., Owuamanam, C.I., Ahaotu, N.N., Nwosu, J.N. 2011. Protein improvement in gari by the use of pure cultures of microorganisms involved in the natural fermentation process. Pakistan Journal Biological Science, 14, 933-938.

Amoa-Awua, W.K., Frisvad, J.C., Sefa-Dedeh, S., Jakobsen, M. 1997. The contribution of moulds and yeasts to the fermentation of 'agbelima' cassava dough. Journal of Applied Microbiology, 83:288-296.

AOAC. 1990. Official Method of Analysis. 15 ${ }^{\text {th }}$ Edn. Association of Official Analytical Chemist Washington D.C.

Aro, S.O. Aletor, V.A., Tewe, O.O., Agbede, J.O. 2010. Nutritional potentials of cassavatuber wastes: a case study of a cassava starch processing factory in south-western Nigeria. Livestock Research and Rural Development, 22, 44-50.

Asaolu, V., Binuomote, R., Akinlade, J., Aderinola, O., Oyelami, O. 2012. Intake and growth performance of West African dwarf goats fed Moringa oleifera, Gliricidia sepium and Leucaena leucocephala dried leaves as supplements to cassava peels. Journal of Biological and Agricultural Healthcare. 2, 76-88.

Barrow, G.I., Feltham, R.K.A. 2003. Cowan and Steel's manual for identification of medical bacteria. Cambridge University Press. Cambridge.

Burns, R.E. 1971. Method for estimation of tannin in grain sorghum. Agronomy. Journal, 3, 511-512.

Burns, A.E., Gleadow, R. M., Zacarias, A.M., Cuambe, C.E., Miller, R.E., Cavagnaro, T.R. 2012. Variations in the chemical composition of cassava (Manihot esculenta Crantz) leaves and roots as affected by genotypic and environmental variation. Journal of Agricultural and Food Chemistry, 60, 4946-4956.

Carafoli, E. 1991. Calcium pump of the plasma membrane. Physiology Review, 71, 129-153.

Cardoso, P.A., Mirione, E., Ernesto, M., Fernando, M., Julie, C., Rezaul, H.M., Bradbury, J.H. 2005. Processing of cassava roots to remove cyanogens. Journal of Food Composition and Analysis, 18, 451- 460

Chisenga, S.M., Workneh, T.S., Bultosa, G., Laing, M. 2019. Proximate composition cyanide contents, and particle size distribution of cassava flour from cassava varieties in Zambia. AIMS Agriculture and Food, 4, 869-891. 
Coulin, P., Farah, Z., Assanvo, J., Spillmann, H., Puhan, Z. 2006. Characterisation of the microflora of 'attieke', a fermented 'cassava product, during traditional small-scale preparation. International Journal of Food Microbiology, 106:131-136.

Dai, J., Tao, L., Shi, C., Yang, S., Li, D., Sheng, J., Tian, Y. 2020. Fermentation improves calcium bioavailability in Moringa oleifera leaves and prevents bone loss in calciumdeficient rats. Food Science and.Nutrition, 8, 3692-3703.

Duodu, K.G., Apea-Bah, F.B. 2017. African Legumes: Nutritional and Health-Promoting Attributes. In: Gluten-Free Ancient Grains, Taylor, J.R.N. Awika. J.M. Eds. Woodhead Publishing, pp. 223-269.

Ebabhi, A.M., Adekunle, A.A., Okunowo, W.O., Osuntoki, A.A. 2013. Isolation and characterization of yeast strains from local food crops. Journal of Yeast and Fungal Research, 4: 38-43

Enneking, D., Wink, M. 2000. Towards the elimination of antinutritional factors in grain legumes. In: Current Plant Science and Biotechnology in Agriculture, Knight, R. Ed, 375384. Kluwer Academic Publishers, Dordrecht/Boston/London, pp 375-384.

Ezekiel, O.O., Aworh, O.C., Blaschek, H.P., Ezeji T.C. 2010. Protein enrichment of cassava peel by submerged fermentation with Trichoderma viride ATCC 36316. African Journal of Biotechnology, 9, 187-194.

FAO. 2001. Strategic environmental assessment: an assessment of the impact of cassava production and processing on the environment and biodiversity. Proceedings of the validation forum on the global cassava development strategy, 5, 26-28.

Gruhnert, C., Biehl, B., Selmar, D. 1994. Compartmentation of cyanogenic glucosides and their degrading enzymes. Planta, 195, 36-42.

Gunorubon, A.J. 2012. Production of cassava starch-based adhesive. Research Journal in Engineering and Applied Sciences, 1, 219-214.

Hasmadi, M., Harlina, L., Jau-Shya, L., Mansoor, A.H., Jahurul, M.H.A. Zainol, M.K. 2020. Physicochemical and functional properties of cassava flour grown in different locations in Sabah, Malaysia. Food Research, 4, 991 - 999.

Hernandez, O.M., Fraga, J.M.G., Jimenez, A.I., Jimenez, F. Arias, J.J. 2004. Characterization of honey from the Canary Islands: determination of the mineral content by atomic absorption spectrophotometry. Food Chemistry, 93, 449-458.

Iyayi, E.A., Losel, D.M. 2001. Protein enrichment of cassava by-product through solid state fermentation by fungi. Journal of Food Technology in Africa, 6,116-118.

Kasaye, T., Melese, A., Amare, G., Hailaye, G. 2018. Effect of fermentation and boiling on functional and physic-chemical properties of yam and cassava flours. Journal of Agriulture, Science and Food Research, 9, 244.

Kolapo, A.L., Sanni, M.O. 2009. A comparative evaluation of the macronutrient and micronutrient profiles of soybean-fortified gari and tapioca. Food Nutrition Bulletin, 30, 91-95.

Kwon, D.Y., Nyakudya, E., Jeong, Y.S. 2014. Fermentation: Food Products. In: Encyclopedia of Agriculture and Food Systems, Van Alfen, N.K. Ed., Academic Press, pp. 113-123.

Lacerda, I.C.A., Miranda, R.L., Borelli, B.M., Nunes, A.C., Nardi, R.M.D., Lachance, M.A., Rosa, C.A. 2005. Lactic acid bacteria and yeasts associated with spontaneous fermentations during the production of sour cassava starch in Brazil. International Journal of Food Microbiology, 105:213-219. 
Lei, V., Amoa-Awua, W.K.A., Brimer, L., 1999. Degradation of cyanogenic glycosides by Lactobacillus plantarum isolates from spontaneous cassava fermentation and other microorganisms. International Journal of Food Microbiology, 53, 169-184.

Lukuyu, B., Okike, I., Duncan, A., Beveridge, M., Blümmel, M. 2014. Use of cassav in livestock and aquaculture feeding programs. ILRI Discussion Paper 25. International Livestock Research Institute. Nairobi, Kenya.

Ma, G., Jin, Y., Piao, J., Kok, F., Guusje, B., Jacobsen, E. 2005. Phytate, calcium, iron, and zinc contents and their molar ratios in foods commonly consumed in China. Journal of Agricultural Food Chemistry, 53, 10285- 10290.

Manano, J., Ogwok, P. and Byarugaba-Bazirake, G. W. 2018. Chemical Composition of Major Cassava Varieties in Uganda, Targeted for Industrialisation. Journal of Food Research, 7, 1-9.

Marfo, E.K., Simpson, B.K., Idowu, J.S., Oke, O.L. 1990. Effect of local food processing on phytate levels in cassava, cocoyam, yam, maize, sorghum, rice, cowpea, and soybean. Journal of Agricultural Food Chemistry, 38, 1580-1585.

Montagnac, J.A., Davis, C.R., Tanumihardjo, S.A. 2009. Processing techniques to reduce toxicity and antinutrients of cassava for use as a staple food. Comprehensive Review in Food Sciience and Food Safety, 8, 17-27.

Moriasi, G.A., Olela, B.O., Waiganjo, B.W., Wakori, E.W.T., Onyancha, J.M. 2017. Evaluation of cyanide levels in two cassava varieties (Mariwa and Nyakatanegi) grown in Baragulu, Siaya County, Kenya. Journal of Food and Nutrition Research, 5, 817-823.

Mutayoba, S.K., Fauquet, C.M., Dierenfeld, E.S. 2012. Nutritional evaluation of Cassava (Manihot esculenta) fractions (flesh, peels, and leaf) from select cultivars. Global Cassava Partnership for the 21st Century. Entebbe, Uganda.

Nambisan, B., Sundaresan, S. 1985. Effect of processing on the cyanoglucoside content of cassava. Journal of Science Food and Agriculture, 36, 1197-2203.

Ndam, Y.N., Mounjouenpou, P., Kansci, G., Kenfack, M.J., Meguia, M.P.F., Eyenga, N.S.N.N., Akhobakoh, M.M., Nyegue, A. 2019. Influence of cultivars and processing methods on the cyanide contents of cassava (Manihot esculenta Crantz) and its traditional food products. Scientific African, 5, e00119

Oboh, G., Oladunmoye, M.K. 2007. Biochemical changes in micro-fungi fermented cassava flour produced from low- and medium-cyanide variety of cassava tubers. Nutrition and Health, 18, 355-367.

Oboh, G. 2006. Nutrient enrichment of cassava peels using a mixed culture of Saccharomyces cerevisae and Lactobacillus sp. solid media fermentation techniques. Electronic Journal of Biotechnology, 9, 46-49.

Ogiehor, I.S., Ikenebomeh, M.J. 2005. Extension of shelf life of garri by hygienic handling and sodium benzoate treatment. African Journal of Biotechnology and Microbiology, 47, 744-748.

Okoli, I.C. 2020.Cassava Waste as Feedstuff 1: Cassava peel production, processing, and nutrient composition. Research Tropica. https://researchtropica.com/cassava-waste-asfeedstuff-1/ Accessed 12/03/2021

Oloruntola, O.D., Ayodele, S.O., Jimoh, O.A., Agbede, J.O. 2019. Dietary cassava peel meal, methionine, and multi-enzyme supplementation in rabbits' nutrition:effect on growth, digestibility, and carcass traits The Journal of Basic and Applied Zoology, 80:46. 
Olukanni, D.O., Olatunji, T.O. 2018. Cassava Waste Management and Biogas Generation Potential in Selected Local Government Areas in Ogun State, Nigeria. Recycling, 3, 58

Omede, A.K., Ahiwe, E.U., Zhu, Z.Y., Fru-Nji, F., Ade, P. 2017. Improving cassava quality for poultry feeding through application of biotechnology. In: Cassava. Waisundara, V.Y. Ed, Intechopen, London.

Oyewole, O.B. 2001. Characteristics and significance of yeasts involvement in cassava fermentation for 'fufu' production. International Journal of Food Microbiology. 65:213218.

PWC 2020. Harnessing the economic potential of cassava production in Nigeria. Retrieved on October 06, 2020 from https://www.pwc.com/ng/en/publications/economic-potentialof-cassava-production-in-nigeria.html.

Salami, R.I., Odunsi, A.A. 2003. Evaluation of processed cassava peel meals as substitutesfor maize in the diets of layers. International Journal of Poultry Science, 2, 112-116.

Schwan, R.F., Almeida, E.G., Souza-Dias, M.A.G., Jespersen, L. 2007. Yeast diversity in rice-cassava fermentations produced by the indigenous Tapirape people of Brazil. FEMS Yeast Research, 7:966-972.

Siritunga, D., Sayre, R.T. 2003. Generation of cyanogen-free transgenic cassava. Planta, 217, 367-73.

Smith, O.B. 1988. A review of ruminant responses to cassava-based diets. In: Cassava as livestock in Africa. Hahn, S.K. Reynolds, L. Egbunike, G. N. (Eds), Proceedings of the IITA/ILCA/University of Ibadan 1988 Workshop pp. 39-53.

Solomon, S.G., Lamai, S.L., Tiamiyu, L.O. 1999. Studies on the nutritional value of cassava (Manihot utillisima) peels as energy source in the diet of Oreochromis niloticus fry fed in indoor glass aquaria. In: $13^{\text {th }}$ Annual Conference of the Fisheries Society of Nigeria (FISON), 3-8 November 1996, New Bussa, Nigeria, pp. 76-83.

Unigwe C.R., Fasanmi, O.G., Okorafor, U.P., Nwufoh, O.C., Oladele-Bukola, M.O. 2014. Replacement value of sundried cassava peels meal for maize on growth performance and haematology of grower pigs. Scholar Academic Journal of Bioscience, 2, 27-32.

Vasconcellos, S.P., Cereda, M.P., Cagnon, J.R., Foglio, M.A., Rodrigues, R.A., Manfio, G.P. and Oliveira, V.M. 2009. In vitro degradation of linamarin by microorganisms isolated from cassava wastewater treatment Lagoons. Brazilian Journal of Microbiology, 40: 879883. 